\title{
Synthesis and Characterization of New Azo Dye Complexes with Selected Metal Ions
}

\author{
Amer J. Jarad \\ Department of Chemistry, Ibn-Al-Haithem Education College, University of Baghdad, \\ Baghdad-Iraq.
}

\begin{abstract}
Coupling reaction of 2-amino benzoic acid with phenol gave the new bidentate azo ligand. The prepared ligand was identified by Microelemental Analysis, FT-IR and UV-Vis spectroscopic technique. Treatment of the prepared ligand with the following metal ions $\left(\mathrm{Co}^{\mathrm{II}}, \mathrm{Ni}^{\mathrm{II}}, \mathrm{Cu}^{\mathrm{II}}\right.$ and $\left.\mathrm{Zn}^{\mathrm{II}}\right)$ in aqueous ethanol with a 1:2 M:L ratio and at optimum $\mathrm{pH}$, yielded a series of neutral complexes of the general formula $\left[\mathrm{M}(\mathrm{L})_{2}\right]$. The prepared complexes were characterized using flame atomic absorption, (C.H.N) Analysis, FT-IR and UV-Vis spectroscopic methods as well as magnetic susceptibility and conductivity measurements. The nature of the complexes formed were studied following the mole ratio and continuous variation methods, Beer's law obeyed over a concentration range $\left(1 \times 10^{-4}-3 \times 10^{-4} \mathrm{M}\right)$. High molar absorbtivity of the complex solutions were observed. The stability constant of the complexes have also been studied.
\end{abstract}

Keywords: Azo-dyes, azo-aromatic ligand, synthesis, azo complexes

\section{Introduction}

Azo compounds are a very important class of chemical compounds receiving attention in scientific research. They are highly colored and have been used as dyes and pigments for a long time ${ }^{[1-3]}$. Furthermore, they have been studied widely because of their excellent thermal and optical properties in applications such as optical recording medium ${ }^{[4-7]}$, toner $^{[8,9]}$, ink-jet printing ${ }^{[10,11]}$, and oil-soluble lightfast dyes ${ }^{[12]}$. Recently, azo metal chelates have also attracted increasing attention due to their interesting electronic and geometrical features in connection with their application for molecular memory storage, nonlinear optical elements and printing systems ${ }^{[13]}$. In this respect an attempt has been made to synthesize and characterize a new azo bidenteate ligand derived from 2-amino benzoic acid as diazo component, and phenol as coupling agent. The complexes of this ligand with some metal ions has also been studied and characterized physicochemically.

\section{Experimental \\ Instrumentation}

UV-Vis spectra were recorded on a (Shimadzu UV- 160A) Ultra Violet-Visible Spectrophotometer. IR- spectra were taken on a (Shimadzu, FTI R- 8400S) Fourier Transform Infrared Spectrophotometer (4000$400) \mathrm{cm}^{-1}$ with samples prepared as $\mathrm{KBr}$ discs. Atomic absorption were obtained using a
(Shimadzu A.A-160A) Atomic Absorption /Flame Emission Spectrophotometer. Microelemental analysis (C. H. N) were performed in Al- al- Bayt University- Jordan using (Euro vector EA 3000A Elemental Analyser). Conductivities were measured for $10^{-3} \mathrm{M}$ of complexes in ethanol at $25^{\circ} \mathrm{C}$ using (Philips PW-Digital Conductimeter). Magnetic susceptibilities were performed using (Brucker Magnet B. M. 6) instrument at $25^{\circ} \mathrm{C}$. In addition melting points were obtained using (Stuart Melting Point Apparatus).

\section{Materials and Reagents}

The following chemicals were used as received from suppliers; cobaltous chloride hexahydrate $98.8 \%$, nickel chloride hexahydrate $99.9 \%$, copper chloride dihydrate 98\%, zinc chloride 99\% (Merck) 2- amino benzoic acid $98.8 \%$, phenol $99 \%$ (B. D. H).

The $\mathrm{pH}$ of the medium (5-7.5) were adjusted with ammonium acetate -ammonia glacial acetic acid buffer solution.

Solutions were made of the ligand $\left(1 \times 10^{-5}\right.$ $\left.1 \times 10^{-3} \mathrm{M}\right)$ in absolute ethanol and same concentration range of metals salts in buffer solutions

\section{Preparation of the Ligand}

$(0.34 \mathrm{~g}, 1 \mathrm{mmole})$ of 2 - amino benzoic acid was dissolved in a mixture of $(2 \mathrm{ml})$ sulphuric acid, $(10 \mathrm{ml})$ ethanol and $(10 \mathrm{ml})$ distilled water, and diazotized at $5^{\circ} \mathrm{C}$ with sodium 
nitrite solution. The diazo solution was added dropwise with stirring to a cooled ethanolic solution of $(0.23 \mathrm{~g}, 1 \mathrm{mmole})$ of phenol. $(25 \mathrm{ml})$ of ( $1 \mathrm{M})$ sodium hydroxide solution was added to the dark colored mixture. The precipitate was filtered off and washed several times with (1: 1) ethanol: water, mixture then left to dry. The reaction is shown in Fig. (1). The physical properties and elemental and analysis are listed in Table (1).

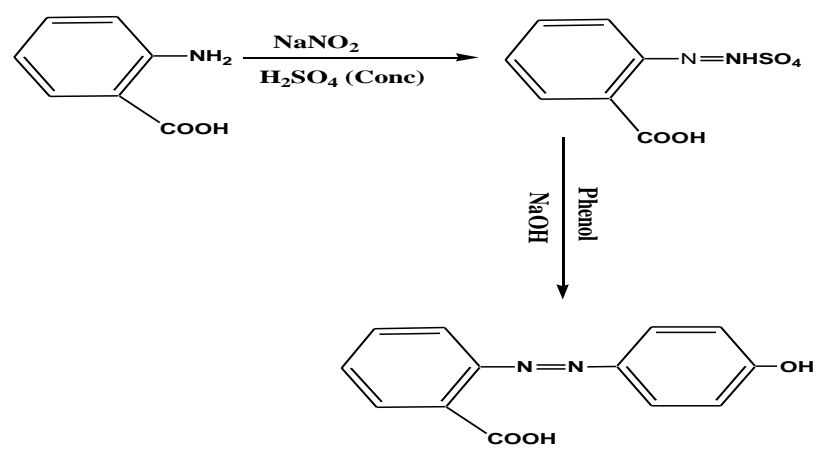

Fig.(1) Preparation of the Ligand.

Table (1)

Physical Properties and Elemental Analysis of the Ligand and Its Complexes.

\begin{tabular}{|c|c|c|c|c|c|c|c|}
\hline \multirow[b]{2}{*}{ Compounds } & \multirow[b]{2}{*}{ Color } & \multirow[b]{2}{*}{ M.P $P^{\circ} C$} & \multirow{2}{*}{$\begin{array}{c}\text { Yield } \\
\%\end{array}$} & \multicolumn{4}{|c|}{ Analysis Calc.(Found) } \\
\hline & & & & $\begin{array}{c}\text { M\% } \\
\text { (Metal) }\end{array}$ & $\mathrm{C} \%$ & $\mathrm{H \%}$ & $N \%$ \\
\hline Ligand & Orange & 210 & 88 & - & $\begin{array}{c}64.46 \\
(63.95) \\
\end{array}$ & $\begin{array}{c}4.13 \\
(4.02)\end{array}$ & $\begin{array}{c}11.57 \\
(11.23) \\
\end{array}$ \\
\hline$\left[\mathrm{Co}(\mathrm{L})_{2}\right]$ & Brown & $>360$ & 80 & $\begin{array}{c}10.90 \\
(10.51)\end{array}$ & $\begin{array}{c}60.70 \\
(60.05) \\
\end{array}$ & $\begin{array}{c}3.50 \\
(3.31) \\
\end{array}$ & $\begin{array}{l}10.34 \\
(9.93) \\
\end{array}$ \\
\hline$\left[\mathrm{Ni}(\mathrm{L})_{2}\right]$ & $\begin{array}{l}\text { Reddish } \\
\text { Orange }\end{array}$ & $>360$ & 78 & $\begin{array}{c}10.74 \\
(10.04)\end{array}$ & $\begin{array}{c}57.77 \\
(57.12)\end{array}$ & $\begin{array}{c}3.33 \\
(3.01)\end{array}$ & $\begin{array}{c}10.37 \\
(10.07) \\
\end{array}$ \\
\hline$\left[\mathrm{Cu}(\mathrm{L})_{2}\right]$ & $\begin{array}{c}\text { Yellowish } \\
\text { Orange }\end{array}$ & $>360$ & 72 & $\begin{array}{c}11.72 \\
(11.12)\end{array}$ & $\begin{array}{c}57.14 \\
(56.90)\end{array}$ & $\begin{array}{c}3.29 \\
(2.98)\end{array}$ & $\begin{array}{l}10.25 \\
(9.96)\end{array}$ \\
\hline$\left[\mathrm{Zn}(\mathrm{L})_{2}\right]$ & Red & $>360$ & 86 & $\begin{array}{c}11.88 \\
(10.51)\end{array}$ & $\begin{array}{c}57.03 \\
(56.88)\end{array}$ & $\begin{array}{c}3.29 \\
(3.03)\end{array}$ & $\begin{array}{c}10.23 \\
(10.12)\end{array}$ \\
\hline
\end{tabular}

Preparation of Metal Complexes (general procedure)

An ethanolic solution of the ligand $(0.24 \mathrm{~g}$, 2 mmole) was added gradually with stirring to the $0,118 \mathrm{~g}, 0.118 \mathrm{~g}, 0.085 \mathrm{~g}$ and $0.068 \mathrm{~g}$ (1mmole) of $\mathrm{CoCl}_{2} \cdot 6 \mathrm{H}_{2} \mathrm{O}, \quad \mathrm{NiCl}_{2} \cdot 6 \mathrm{H}_{2} \mathrm{O}$, $\mathrm{CuCl}_{2} \cdot 2 \mathrm{H}_{2} \mathrm{O}$ and $\mathrm{ZnCl}_{2}$ respectively dissolved in the buffer solution of the required $\mathrm{pH}$. The mixture was cooled until dark color precipitate was formed, filtered and washed several times with (1: 1) water: ethanol then with acetone.

\section{Results and Discussion}

The ligand was prepared by coupling phenol with the appropriate diazotate in alkaline solution. The ligand sparingly soluble in water but soluble in organic solvents, stable toward air and moisture.

The ligand was characterized by UV-Vis spectroscopic technique. The spectrum of an ethanolic solution of the ligand $\left(10^{-3} \mathrm{M}\right)$ display mainly three peaks, the first and second peaks were observed at $(253 \mathrm{~nm})$ and
(300 $\mathrm{nm}$ ) were assigned to the moderate energy $\pi-\pi^{*}$ transition of the aromatic rings. The third peak $\left(\lambda_{\max }\right)$ was observed at the (424 nm) was referred to the $\pi-\pi^{*}$ transition of intermolecular charge- transfer taken place from benzene through the azo group $(-\mathrm{N}=\mathrm{N})^{[14]}$.

Interaction of the metal ions $\left(\mathrm{Co}^{\mathrm{II}}, \mathrm{Ni}^{\mathrm{II}}\right.$, $\mathrm{Cu}^{\mathrm{II}}$ and $\mathrm{Zn}^{\mathrm{II}}$ ) with the prepared ligand has been studied in solution; An aqueousethanolic solutions were always performed over wide molar concentration and acidity range. The colors of these mixed solutions were varied from brown or reddish orange to red. (Table (1)) described physical properties and elemental analysis.

The interaction of the metal ion with the ligand manifest itself in the absorption spectra by the appearance of a peak in the range (477$520 \mathrm{~nm}$ ). A great bathochromic shift in the visible region was detected in the complex solutions spectra with respect to that of the free ligand. The high shift in the $\left(\lambda_{\max }\right)$ gave a 
good indication for complex formation. spectra of the ligand and $\mathrm{Co}^{\mathrm{II}}$ mixed solution. (Fig.(2)) showed a comparison between the

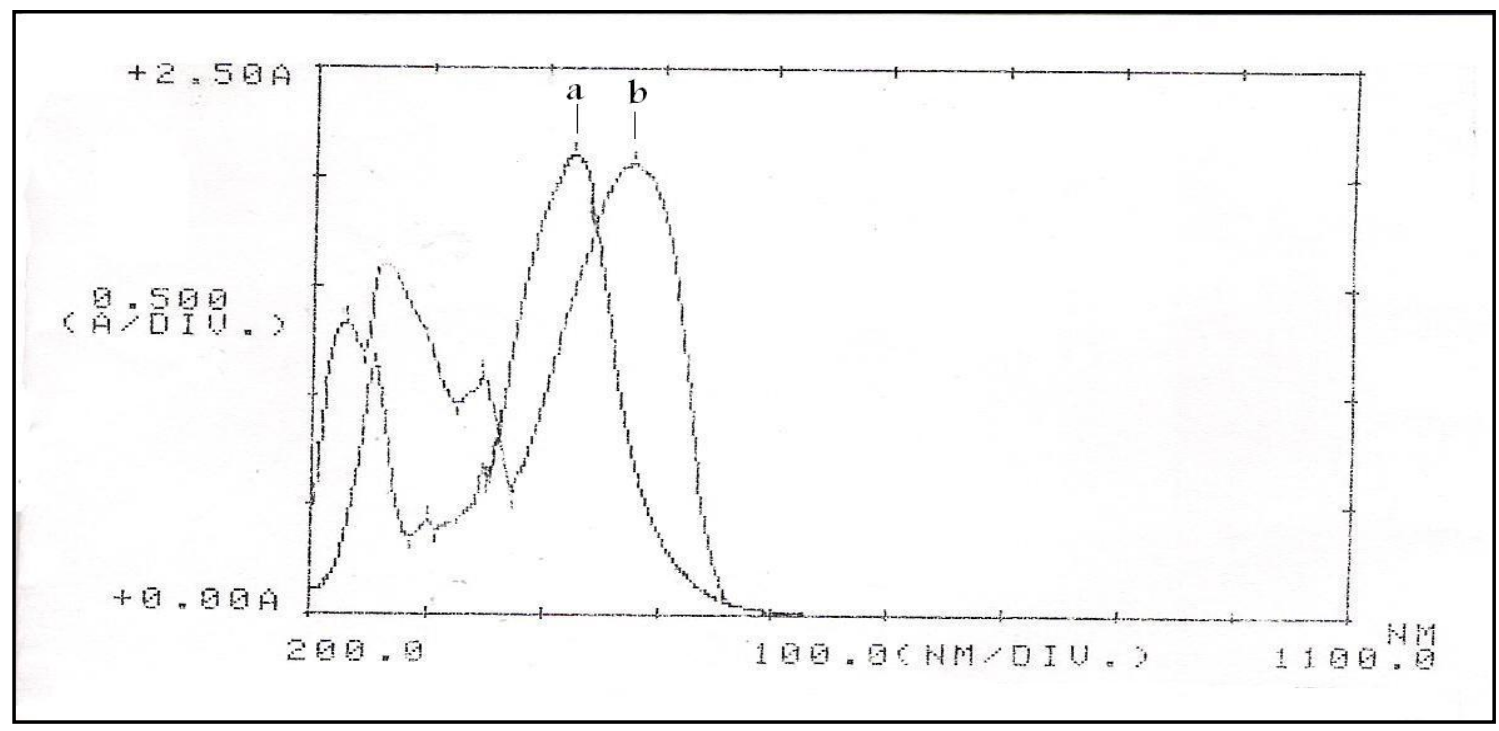

Fig.(2) UV-Vis spectra of a-free Ligand Solution b-Co ${ }^{I I}$ - L Mixed Solution.

From the wide studied range of molar concentration $\left(10^{-5}-10^{-3} \mathrm{M}\right)$ of the mixed solutions, only concentration of $\left(10^{-4} \mathrm{M}\right)$ obey Lambert- Beer's law and showed intense color. A calibration curve was plotted on absorbance against molar concentration in the range $\left(1 \times 10^{-4}-3 \times 10^{-4} \mathrm{M}\right)$. Best fit straight lines were obtained (Fig.(3)) with correlation factor $\mathrm{R}>0.998$.

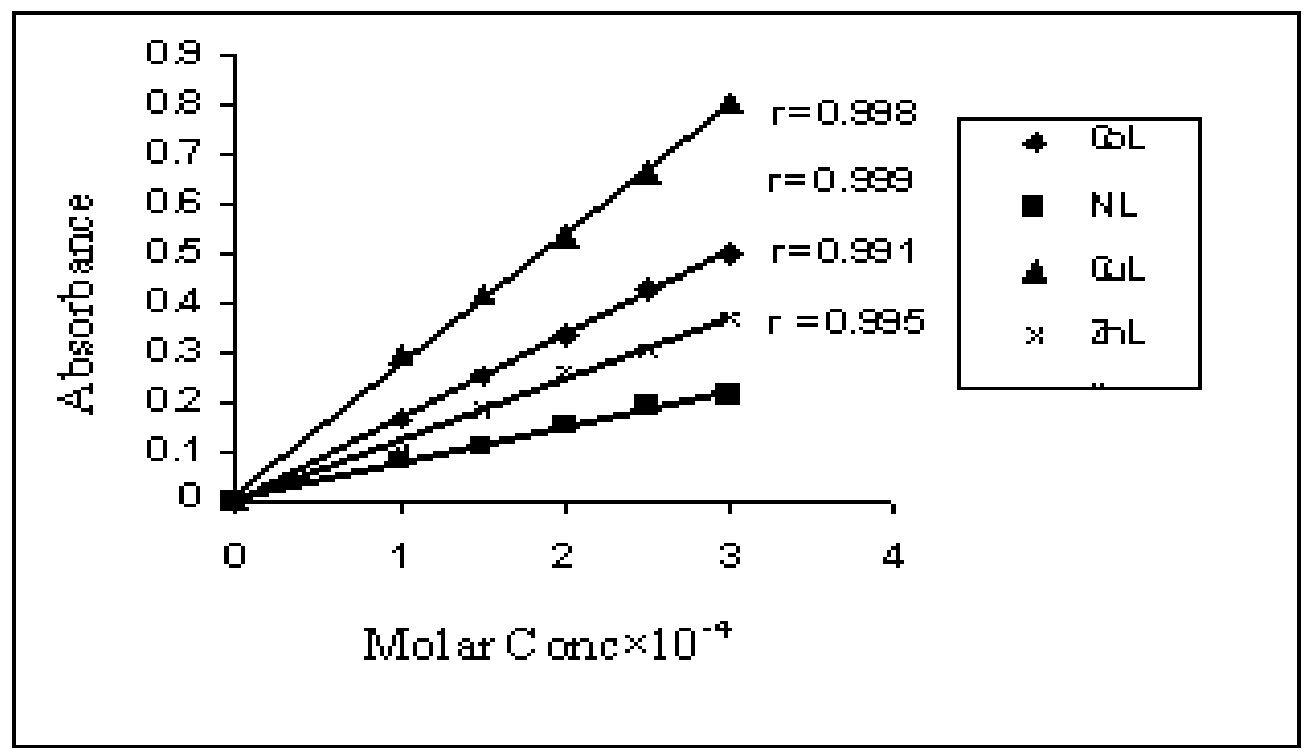

Fig.(3) Linear Relation Between Molar Concentration and Absorbance.

The optimum concentration was chosen for complex solution gave rise to a constant $\left(\lambda_{\max }\right)$ at different $\mathrm{pH}$.

The influence of $\mathrm{pH}$ was also studied at $\mathrm{pH}$ range $(5-7.5)$ and the absorbance- $\mathrm{pH}$ curves for each metal ion measured at certain $\left(\lambda_{\max }\right)$ were plotted. (Fig.(4)) showed a selective $\mathrm{pH}$ absorbance curves. The plateau of the curves represent the completion of the reaction and consequently represent the optimum $\mathrm{pH}$. 


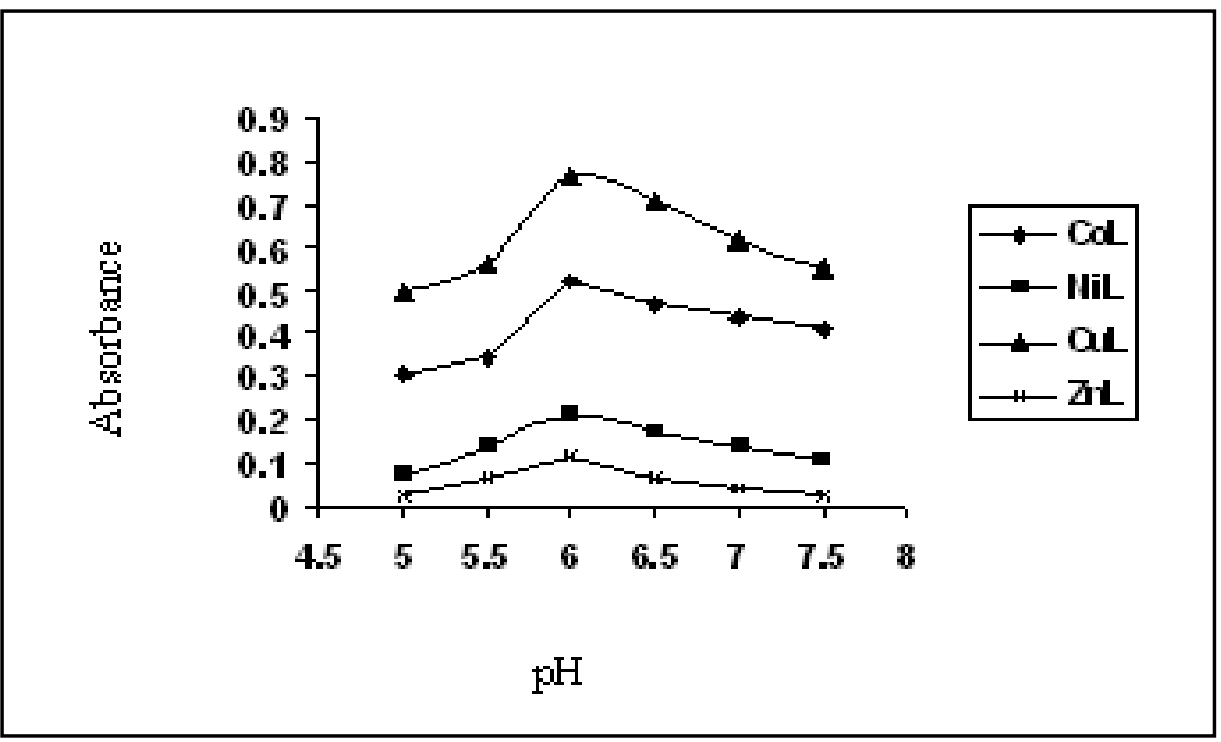

Fig.(4) Effect of pH on Absorbance $\left(\lambda_{\max }\right)$ for Complexes.

The composition of the complexes formed in solution has been established by mole ratio and job methods. In both cases the results reveals (1:2) metal to ligand ratio. A chosen plots of were represented in (Fig.(5)).
(Table (2)) summarize the results obtained as a conditions for the preparation of the complexes
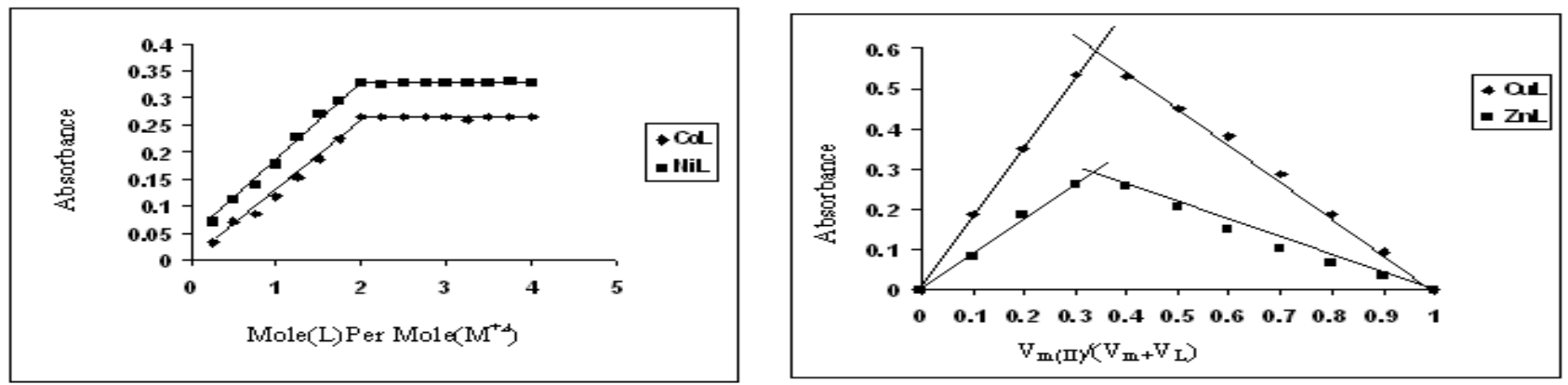

Fig.(5) Mole Ratio and Job Methods for Complexes Solutions.

Table (2)

Conditions for the Preparation of the Complexes and UV-Vis, Magnetic Susceptibility and Conductance Measurements Data.

\begin{tabular}{|c|c|c|c|c|c|c|c|c|}
\hline Compounds & $\begin{array}{c}\text { Optimum } \\
\text { pH }\end{array}$ & $\begin{array}{c}\text { Optimum } \\
\text { Molar } \\
\text { Conc } \\
x 10^{-4}\end{array}$ & $\begin{array}{l}\text { M:L } \\
\text { Ratio }\end{array}$ & $\begin{array}{c}\left(\lambda_{\max }\right) \\
n m\end{array}$ & $A B S$ & $\begin{array}{c}\epsilon_{\max } \\
\left.(\operatorname{L.mol})^{-1} \cdot \mathrm{cm}^{-1}\right)\end{array}$ & $\begin{array}{c}\Lambda_{m}\left(\mathrm{S.cm}^{2} \cdot \mathrm{mol}^{-1}\right) \\
\text { In Absolute } \\
\text { ethanol }\end{array}$ & $\begin{array}{c}\mu_{e f f} \\
(B . M)\end{array}$ \\
\hline Ligand & - & - & - & 424 & 2.105 & 2105 & - & - \\
\hline$\left[\mathrm{Co}(\mathrm{L})_{2}\right]$ & 6 & 2.5 & $1: 2$ & 512 & 0.954 & 954 & 13.63 & 3.81 \\
\hline$\left[\mathrm{Ni}(\mathrm{L})_{2}\right]$ & 6 & 2 & $1: 2$ & 477 & 1.049 & 1049 & 10.86 & 3.04 \\
\hline$\left[\mathrm{Cu}(\mathrm{L})_{2}\right]$ & 6 & 2.5 & $1: 2$ & 492 & 0.744 & 744 & 8.67 & 1.61 \\
\hline$\left[\mathrm{Zn}(\mathrm{L})_{2}\right]$ & 6 & 2.5 & $1: 2$ & 520 & 0.687 & 687 & 15.42 & - \\
\hline
\end{tabular}


The apparent stability constant $(\mathrm{K})$ of the (1:2) metal: ligand complex were evaluated spectroscopically using the following equations:

$$
K=\frac{1-\propto}{4 \propto^{3} c^{2}} \quad \propto=\frac{A_{m}-A_{s}}{A_{m}}
$$

Where $c=$ the concentration of the complex solution in mole/ $\mathrm{L}$

$\mathrm{A}=$ degree of dissociation, $\mathrm{As}=$ the absorption of solution containing a stoichiometric amount of ligand and metal ion and $A m=$ the absorption of solution containing the same amount of metal and excess of ligand.

The As and Am were measured at $\left(\lambda_{\max }\right)$ of solution. The values of (As, Am, $\alpha, \mathrm{K}$ and $\log \mathrm{K}$ ) were tabulated in (Table (3)). The high values of $\mathrm{K}$ may reflect the high stability of the prepared complexes ${ }^{[15]}$.

Table (3)

Stability Constant of the Prepared Complexes.

\begin{tabular}{|c||c|c||c||c|c|}
\hline Complexes & $\boldsymbol{A}_{\boldsymbol{s}}$ & $\boldsymbol{A}_{\boldsymbol{m}}$ & $\boldsymbol{\alpha}$ & $\boldsymbol{k}$ & $\log \boldsymbol{k}$ \\
\hline \hline$\left[\mathrm{Co}(\mathrm{L})_{2}\right]$ & 0.118 & 0.264 & 0.553 & $1.08 \times 10^{6}$ & 6.033 \\
\hline \hline$\left[\mathrm{Ni}(\mathrm{L})_{2}\right]$ & 0.177 & 0.328 & 0.460 & $2.45 \times 10^{6}$ & 6.390 \\
\hline$\left[\mathrm{Cu}(\mathrm{L})_{2}\right]$ & 0.11 & 0.263 & 0.581 & $1.03 \times 10^{6}$ & 6.012 \\
\hline \hline$\left[\mathrm{Zn}(\mathrm{L})_{2}\right]$ & 0.202 & 0.533 & 0.546 & $1.33 \times 10^{6}$ & 6.123 \\
\hline \hline
\end{tabular}

The solid complexes have been prepared by direct reaction of alcoholic solution of the ligand with the aqueous solution of the metal ions at the optimum $\mathrm{pH}$ and in a $(\mathrm{M}: \mathrm{L})$ ratio of (1:2). The (C. H. N) and metal contents of these complexes were in a good agreements with the calculated values.

The molar conductance of the complexes as $\left(10^{-3} \mathrm{M}\right)$ in ethanol indicating their nonelectrolytic nature ${ }^{[16]}$, the data were recorded in (Table (2)). The effective magnetic moments of the complexes lies in the range (1.61-3.81) B.M. This value refers to a paramagnetic (high spin) which has been reported for most tetrahedral geometry ${ }^{[17]}$.

The UV-Vis spectra of the prepared complexes dissolved in ethanol $\left(10^{-3} \mathrm{M}\right)$ have been measured and the data obtained were included in (Table (2)). Again the large bathochromic shift of the $\left(\lambda_{\max }\right)$ assigned to $\left(\pi-\pi^{*}\right)$ transition of the ligand suggesting the involvement of the ligand in the bond formation with the metal ion.
In order to study the binding mode of the new ligand with the metal ions, a comparison have been made for the FT. IR spectra of the free ligand and the prepared complexes and the data was tabulated in (Table (4)). 
Table (4)

The Main Frequencies of the Ligand and Their Complexes $\left(\mathrm{cm}^{-1}\right)$.

\begin{tabular}{|c|c|c|c|c|c|c|c|}
\hline Compounds & $v(\mathrm{OH})$ & $v(C=O)$ & $v_{a s}(C O O)$ & $v_{s}(\mathrm{COO})$ & $\begin{array}{c}v(-N=N-) \\
+ \\
v(-C=N-N=C)\end{array}$ & $v(M-O)$ & $v(M-N)$ \\
\hline Ligand & 3409 br. & $1674 \mathrm{~s}$. & $1604 \mathrm{~m}$. & $1488 \mathrm{~s}$. & $\begin{array}{l}1450 \text { sho. } \\
1373 \text { sho. }\end{array}$ & - & - \\
\hline$\left[\mathrm{Co}(\mathrm{L})_{2}\right]$ & 3402 br. & $1697 \mathrm{~s}$. & 1573 sh. & 1492 sh. & $\begin{array}{l}1458 \mathrm{~s} . \\
1388 \mathrm{sh} .\end{array}$ & 493 w. & 439 w. \\
\hline$\left[\mathrm{Ni}(\mathrm{L})_{2}\right]$ & 3402 br. & 1705 sh. & 1597 sh. & 1492 sh. & $\begin{array}{l}1473 \text { sh. } \\
1450 \text { sh. } \\
1408 \text { sho. }\end{array}$ & 505 w. & 443 w. \\
\hline$\left[\mathrm{Cu}(\mathrm{L})_{2}\right]$ & 3402 br. & $1708 \mathrm{~s}$. & 1577 sh. & $1489 \mathrm{~s}$. & $\begin{array}{c}1473 \text { sho. } \\
1450 \text { sh. } \\
1388 \text { s. }\end{array}$ & 509 w. & 405 w. \\
\hline$\left[\mathrm{Zn}(\mathrm{L})_{2}\right]$ & 3404 br. & 1691s. & $1589 \mathrm{~s}$. & 1489 sh. & $\begin{array}{c}1462 \text { s. } \\
1415 \text { sho. } \\
1373 \text { s. }\end{array}$ & 497 w. & $430 \mathrm{w}$. \\
\hline
\end{tabular}

$r=$ broad,$s=$ strong, $m=$ medium, $s h=$ sharp, sho $=$ shoulder,$w=$ weak, as $=$ asymmetric,$s=$ symmetric

The IR spectrum of the ligand (Fig.(5)) exhibited broad band at $\left(3409 \mathrm{~cm}^{-1}\right)$ was assigned to the stretching vibration of $v(\mathrm{OH})$ of the carboxyl and phenol ${ }^{[18,19]}$.

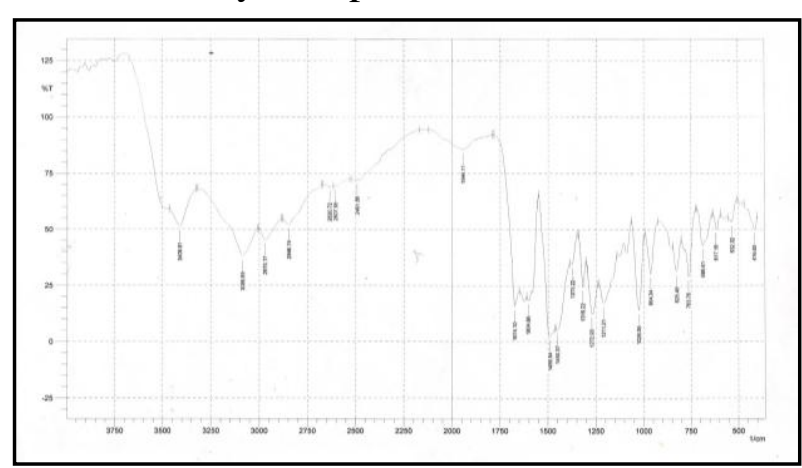

Fig.(6) FT.IR Spectrum of the Ligand .

Strong band in the ligand spectrum was observed at $\left(1674 \mathrm{~cm}^{-1}\right)$ ascribed to the $v(C=O)$ for the carboxyl group. Significant change in the position to higher frequency was also observed on complexation with metal ion. The strong band in the free ligand spectrum at $\left(1604 \mathrm{~cm}^{-1}\right)$ due to $v(\mathrm{COO})$ asymmetric vibration, significant change in the intensity and in position to lower frequency was observed on complexation with metal ion (Fig. $(6,7)$ ).

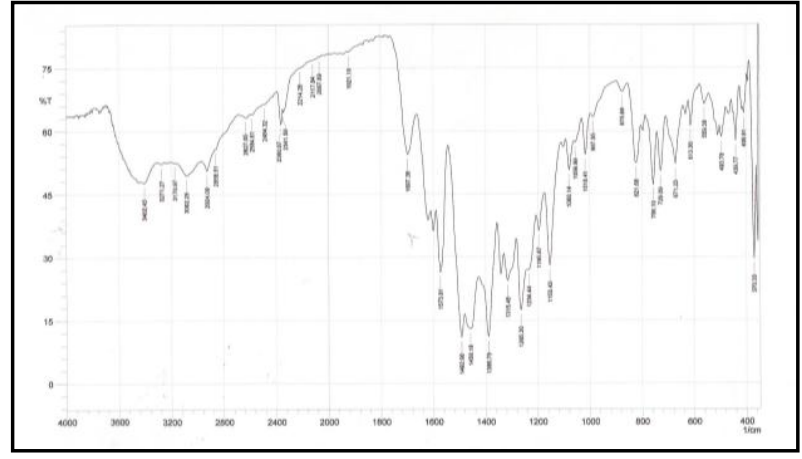

Fig.(7) FT.IR Spectrum of the $\left[\mathrm{Co}(\mathrm{L})_{2}\right]$ Complex. 


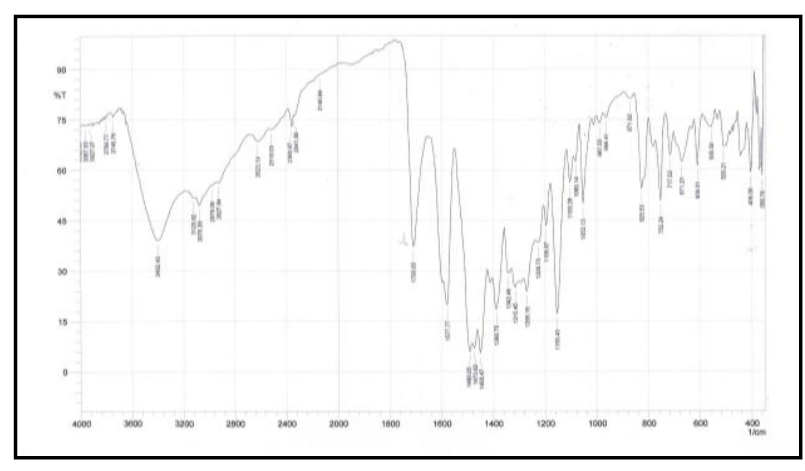

Fig.(8) FT.IR Spectrum of the $\left[\mathrm{Cu}(\mathrm{L})_{2}\right]$ Complex.

The band at $\left(1488 \mathrm{~cm}^{-1}\right)$ in the spectrum of the ligand was assigned to the $v(\mathrm{COO})$ symmetric, suffered a great change to higher frequency on complexation with metal ion [20]. Band characteristic of the azo bridge vibration at $\left(1450 \mathrm{~cm}^{-1}\right)$, on complexation shiften with change in shape or splitting was observed, indicating the engagement of this group in the coordination with metal ion (21). Metal oxygen and nitrogen bands [22,23] further confirmed by the presence of the bands around(493-509) $\mathrm{cm}^{-1}$ and (405-443) $\mathrm{cm}^{-1}$.

According to the results obtained an tetrahedral structure has been suggested to these complexes.

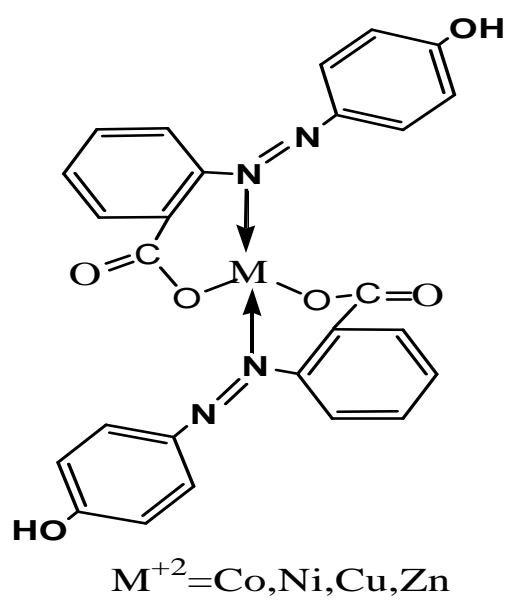

\section{Reference}

[1] Kirkan B. and Gup R.; "Synthesis of New Azo Dyes and Copper(II) Complexes Derived from Barbituric Acid and 4Aminobenz -oylhydrazone"; Turk. $\boldsymbol{J}$. Chem; 32, 9-17, 2008.

[2] SI Y., Hu Q., Huang Z., Yang G. and Yin J.; "Color reaction of 2-(2-Quinolylazo)-5Dimethylamino aniline with Palladium and
Its Application"; Turk. J .Chem; 29, 135140, 2005.

[3] Maradiya H. R. and Patel V. S.; "Synthesis and Application of 2Aminothiadiazol Disperse Dyes for Nylon Fabrics"; J. Serb. Chem. Soc; 66, 87-93, 2001.

[4] Sokolowska-Gajda J., Freeman H. S. and Reife A.; "Synthetic Dyes Based on Environmental Considerate ions"; National Textile Annual Reports; September, 30, 167-175, 1993.

[5] Maradiya H. R.; "Synthesis of Azobenzo (b) Thiophene Derivatives and Their Dyeing Performance on Polyester Fiber"; Turk. $\boldsymbol{J}$. Chem; 25, 441-450, 2001.

[6] Ohashi A., Tsukuda T. and Watara H.; "Structural Isomers in a 2-(5-Bromo-2Pyridylazo)-5-Diethylamino phenolatochloro Palladium(II) Crystal"; Anal. Sci; 19, 1085-1086, 2003.

[7] Karipcin F. and Kabalcilar E.; "Spectroscopic and Thermal Studies on Solid Complexes of 4-(2-Pyridylazo)resorcinol with Some Transition Metals"; Acta. Chim. Slov; 54, 242-247, 2007.

[8] Patel V. H., Petal M. P. and Patel R. G.; "Synthesis and Application of Novel Heterocyclic Dyes Based on 11-amino-13$\mathrm{H}$-acenaphtho [1,2-e] Pyridazin[3,2-b] Quina zolin-13-one";J. Serb. Chem. Soc; 67, 727-737, 2002.

[9] Kupradinun P., Rienkijakaru M., Tanyakaset M., Tepsuwan A. and Kusamran W. R.; "Carcinogenicity Testing of the Cosmetic Dye:D and C Red No.36"; Asian Pacific J. Cancer Prevention; 3, 55-60, 2002.

[10] Maradiya H. r. and Patel V. S.; "Synthesis and Dyeing Performance of Some Novel Hetrocyclic Azo Disperse Dyes"; J.Braz.Chem.Soc; 12, 1-6, 2001.

[11] Gregory P., Waring D. R. and Hallos G.; "The Chemistry and Application of Dyes", plenum press, London, 18-20, 1990.

[12] Kutgen H. K. and Heren Z.; "Thermal Behaviour of Some Azo Dyes Containing Sterically Hindered and Water Soluble Groups"; Turk. J. Chem; 22, 403-408, 1998.

[13] Gavazov K., Lekova V. and Patronov G.; "A Ternary Complex of Vanadium(V) with 
4-(2-Pyridylazo)-resorcinol and Thiazolyl Blue and Its Application"; Acta. Chim. Slov; 53, 506-511, 2006.

[14] Mahmoud M. R., Hamman A. M. and Ibrahim S. A.; "Chromium Complexes of O,O-Dihydroxyazo Dye"; Z. phy. Chem; 265, 203, 1994.

[15] Cao H. W. and Zhao J. F.; "Stability Constants of Cobalt(II) and Copper(II) Complexes with 3-[(O-Carboxy-pnitrobenzene) azo] Chromotropic Acid and Selective Determination of Copper(II) by Competition Coord ination" ; Cro. Chem. Acta; 7, 1-6, 2003.

[16] Geary W. J.; "Characterization of Coordination compounds"; Coord. Chem. $\boldsymbol{R e v} ;$ 7, 110, 1971.

[17] Khulbe R. C. and Singh R. P.; "Chelates of Cobalt(II) and Copper(II) with 1-(2Pyridylazo)-2-phenanthrol and 1-(2Pyridylazo)-2-naphtholl"; Ind. J. Chem; 22A, 214, 1982.

[18] Yildiz E. and Boztpe H.; "Synthesis of Novel Acidic Mono Azo Dyes and an Investigation of Their Use in the Textile Industry";Turk. J. Chem; 26, 897-903, 2002.

[19] Silverstein R. M. and Webster F. X.; "Spectrometric Identification of Organic Compounds"; $6^{\text {th }}$ Ed, New York, John Wiley and Sons, Inc, 180, 1996.

[20] Marcotrigiano G.;"Copper(II) Complexes of Peptide Group Containing Amino Acids";J. Inorg. Nucl. Chem; 39, 18971901, 1977.

[21] Ray U., Banerjee D., Mostafu G., Lu T.H. and Sinha C.;"Copper Coordination Compounds of Chelating Imidazole-azoaryl Ligand"; New. J. Chem; 28, 14371442, 2004.

[22] Gupta C., Kanugo D. K. and P.K. Mehta;" $\mathrm{Mn}(\mathrm{II}), \mathrm{Co}(\mathrm{II}), \mathrm{Ni}(\mathrm{II}), \mathrm{Cu}(\mathrm{II})$ and $\mathrm{Hg}$ (II) Complexes with 5-(2Hydroxyphenyldiazo)-Sialicyladehyde"; $\boldsymbol{J}$. Ind. Chem. Soc; 56, 826, 1979.

[23] Rona A. K. and Shah J. R.; "Spectroscopic Studies of Cobalt (II) Complexes of 2,2-Azopyridines"; J. Ind. Chem. Soc; 58, 1100, 1981.

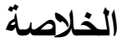

حضرت الليكاند ع-(ب-امينو بنزويك اسد ازو)- فينول

من تفاعل ازدواج r- امينو حامض البنزويك مع (الفينول).

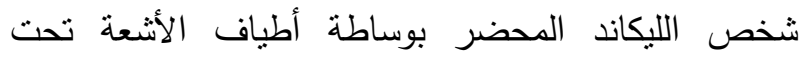

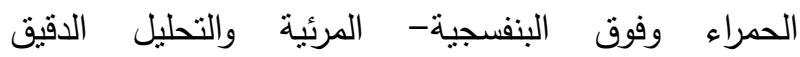

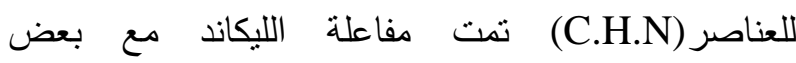

ألايونات ألفلزية المنتخبه $)$ (Zn ${ }^{\mathrm{II}}, \mathrm{Cu}^{\mathrm{II}}, \mathrm{Ni}^{\mathrm{II}}, \mathrm{Co}^{\mathrm{II}}$ في وسط

ايثانول - ماء وبنسبة فلز: ليكاند (2:1) وفي الدانية

الحامضية المتلى، وخضعت محاليل هذه المعقدات لقانون

لامبرت - بير ضمن مدى التراكيز (1)

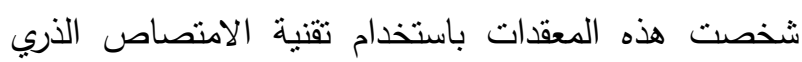

اللهبي، أطياف الأشعة تحت الحمراء والأشعة فوق البنفسجية

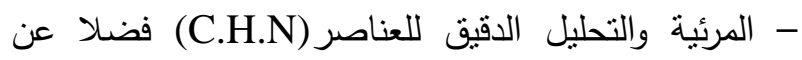

قياسات الحساسية المغناطيسية والتوصيلية الكهربائية. درست

تراكيب المعقدات باستخدام طريقتي النسب المولية والمتغيرات المستمرة، كما نم حساب استقرارية المعقدات المحضرة. 